\title{
The endogenous production of hydrogen sulphide in intrauterine
} tissues

\author{
Pushpa Patel ${ }^{1}$, Manu Vatish ${ }^{2}$, John Heptinstall ${ }^{3}$, Rui Wang ${ }^{4}$ and \\ Ray J Carson*5
}

Address: ${ }^{1}$ College of Medical \& Dental Sciences, University of Birmingham, Birmingham, UK, ${ }^{2}$ Molecular Medicine Research Group, University of Warwick, Coventry, UK, ${ }^{3}$ Biomolecular Sciences Dept., Coventry University, Coventry, UK, ${ }^{4}$ Department of Biology, Lakehead University, Thunder Bay, Ontario, Canada and ${ }^{5}$ Dept of Medical \& Social Care Education, School of Medicine, University of Leicester, Leicester, UK

Email: Pushpa Patel - p.patel.2@bham.ac.uk; Manu Vatish - M.Vatish@warwick.ac.uk; John Heptinstall - J.Heptinstall@coventry.ac.uk; Rui Wang - rwang@lakeheadu.ca; Ray J Carson* - rjc52@le.ac.uk

* Corresponding author

Published: 6 February 2009

Reproductive Biology and Endocrinology 2009, 7:10 doi:10.1186/1477-7827-7-10

This article is available from: http://www.rbej.com/content/7/1/10

(C) 2009 Patel et al; licensee BioMed Central Ltd.

This is an Open Access article distributed under the terms of the Creative Commons Attribution License (http://creativecommons.org/licenses/by/2.0), which permits unrestricted use, distribution, and reproduction in any medium, provided the original work is properly cited.

\begin{abstract}
Background: Hydrogen sulphide is a gas signalling molecule which is produced endogenously from L-cysteine via the enzymes cystathionine beta-synthase (CBS) and cystathionine gamma-lyase (CSE). The possible role of hydrogen sulphide in reproduction has not yet been fully investigated. It has been previously demonstrated that hydrogen sulphide relaxes uterine smooth muscle in vitro. The aim of the present study was to investigate the endogenous production of hydrogen sulphide in rat and human intrauterine tissues in vitro.
\end{abstract}

Methods: The production of hydrogen sulphide in rat and human intrauterine tissues was measured in vitro using a standard technique. The expression of CBS and CSE was also investigated in rat and human intrauterine tissues via Western blotting. Furthermore, the effects of nitric oxide (NO) and low oxygen conditions on the production rates of hydrogen sulphide were investigated.

Results: The order of hydrogen sulphide production rates (mean $+/-S D, n=4)$ for rat tissues were: liver $(777+/-163 \mathrm{nM} / \mathrm{min} / \mathrm{g})>$ uterus $(168+/-100 \mathrm{nM} / \mathrm{min} / \mathrm{g})>$ fetal membranes $(22.3+/-$ $15.0 \mathrm{nM} / \mathrm{min} / \mathrm{g})>$ placenta $(\mathrm{II} . \mathrm{I}+/-4.7 \mathrm{nM} / \mathrm{min} / \mathrm{g})$, compared to human placenta $(200+/-102 \mathrm{nM} /$ $\mathrm{min} / \mathrm{g})$. NO significantly increased hydrogen sulphide production in rat fetal membranes $(P<0.05)$. Under low oxygen conditions the production of hydrogen sulphide was significantly elevated in human placenta, rat liver, uterus and fetal membranes $(P<0.05)$. Western blotting $(n=4)$ detected the expression of CBS and CSE in all rat intrauterine tissues, and in human placenta, myometrium, amnion and chorion.

Conclusion: Rat and human intrauterine tissues produce hydrogen sulphide in vitro possibly via CBS and CSE enzymes. NO increased the production of hydrogen sulphide in rat fetal membranes. The augmentation of hydrogen sulphide production in human intrauterine tissues in a low oxygen environment could have a role in pathophysiology of pregnancy. 


\section{Background}

The pharmacological, physiological and pathological roles of gasotransmitters nitric oxide (NO) and carbon monoxide (CO) have been extensively researched in the reproductive system. NO donors have been demonstrated to relax the myometrium [1] and maintain uterine quiescence [2]. $\mathrm{CO}$ has been demonstrated to relax smooth muscle, including human myometrium via a sGC-cGMP mechanism [3]. Hydrogen sulphide $\left(\mathrm{H}_{2} \mathrm{~S}\right)$ is another gasotransmitter that has many parallels with $\mathrm{NO}$ and $\mathrm{CO}$ [4], however there are no reports to date on the production of $\mathrm{H}_{2} \mathrm{~S}$ in reproductive tissues. $\mathrm{H}_{2} \mathrm{~S}$ is endogenously produced from L-cysteine by two pyridoxal 5' phosphatedependent enzymes cystathionine $\beta$-synthase (CBS) and cystathionine $\gamma$-lyase (CSE) [5-7]. A high expression of CBS has been found in the central nervous system [8] while CSE is highly expressed in vascular tissues in the rat [9]. An early study by Smythe [10] observed the production of $\mathrm{H}_{2} \mathrm{~S}$ in rat liver from L-cysteine. In more recent studies various mammalian tissues have been shown to produce $\mathrm{H}_{2} \mathrm{~S}$, including the brain $(50-160 \mu \mathrm{M})$, the ileum, the kidneys and vascular tissue $[8,11,12]$.

The physiological roles of $\mathrm{H}_{2} \mathrm{~S}$ have been well established. Abe and Kimura [8] suggested possible role of $\mathrm{H}_{2} \mathrm{~S}$ as an endogenous neuromodulator in rat brain tissue, where it is involved in synaptic transmission. In the cardiovascular system $\mathrm{H}_{2} \mathrm{~S}$ acts as a vasodilator both in vivo and in vitro and reduces blood pressure in vivo. The mechanism of action of $\mathrm{H}_{2} \mathrm{~S}$ is unknown. However, unlike $\mathrm{NO}, \mathrm{H}_{2} \mathrm{~S}$ dilates blood vessels possibly via a novel mechanism that involves the opening of $\mathrm{K}^{+}$ATP channels [13]. The role of $\mathrm{H}_{2} \mathrm{~S}$ as an inflammatory mediator is supported by the pharmacological inhibition of $\mathrm{H}_{2} \mathrm{~S}$ biosynthesis by the CSE enzyme inhibitor D,L-propargylglycine or $\beta$-cyano-Lalanine in conditions such as acute pancreatitis, haemorrhagic shock and endotoxemia [14-16]. $\mathrm{H}_{2} \mathrm{~S}$ as a smooth muscle relaxant has been investigated in various smooth muscle tissues. The $\mathrm{H}_{2} \mathrm{~S}$ donor sodium hydrosulphide (NaHS) relaxed guinea pig and rat ileum smooth muscle and also the thoracic aorta and portal vein $[11,17]$. Sidhu et al. [18] showed that NaHS relaxed isolated pregnant rat uterine strips in vitro, demonstrating the role of $\mathrm{H}_{2} \mathrm{~S}$ as a smooth muscle relaxant. However the study did not investigate the production of $\mathrm{H}_{2} \mathrm{~S}$ or the expression of the CBS and CSE enzymes in intrauterine tissues, and this has not been reported previously.

The aim of the present study was to investigate the endogenous production of $\mathrm{H}_{2} \mathrm{~S}$ and identify the expression of CBS and CSE enzymes in rat and human intrauterine tissues.

\section{Methods \\ Tissue collection}

Tissue was collected from 36 pregnant Sprague-Dawley rats (175-250 g) at 19 days of gestation and from 4 nonpregnant Sprague-Dawley rats in the proestrous stage of the oestrous cycle, in accordance with the Home Office Guidance on the Operation of Animals (Scientific Procedures) Act 1986. Rat tissue was collected at 19 days of gestation as samples were required close to term, but not at term, which corresponds to a time frame in human pregnancy when premature labour or pre-eclampsia could occur. In pregnant rats, the uterus was incised and samples of the amnion were dissected from the complete amniotic sac, placentas were then removed from their attachment sites and cleaned of any fetal membrane attachments. Finally, whole samples of uterus were dissected out and retained. In non-pregnant rats samples of the whole uterus were dissected out. Samples of liver were retained from each animal in order to provide positive controls. All tissue samples were washed with sterile saline to remove excess blood.

Human placentas with attached amnion and myometrial samples were collected at four elective Caesarean sections at term from normal pregnancies with informed consent from the Women's Unit at University Hospital Coventry and Warwickshire, with ethical approval from Coventry Local Research Ethics Committee. Samples of amnion were removed from the placentas and $2 \mathrm{~cm}$ core samples of the placenta were obtained. Small samples of myometrium were retained during the Caesarean section procedure. Unfortunately, samples from pre-eclamptic placentas were not available in sufficient numbers for statistical comparison. All tissue samples were washed with sterile saline to remove excess blood and were stored at $80^{\circ} \mathrm{C}$ until use.

\section{Endogenous production of $\mathrm{H}_{2} \mathrm{~S}$}

The endogenous production of $\mathrm{H}_{2} \mathrm{~S}$ was measured using the methylene blue assay method of Zhao et al. [12] with modifications. Ten grams of tissue were homogenised in 6-9 $\mathrm{ml}$ of ice-cold $50 \mathrm{mM}$ potassium phosphate buffer (pH 6.8). Fifty percent tissue homogenate was added to ten $30 \mathrm{ml}$ capacity universal containers loaded with a reaction mixture of $100 \mathrm{mM}$ potassium phosphate buffer $(\mathrm{pH}$ 7.4), $2 \mathrm{mM}$ pyridoxal 5'phosphate and $10 \mathrm{mM}$ L-cysteine. Small plastic test tubes were used as centre wells containing $1 \%$ zinc acetate $(0.5 \mathrm{ml})$ with a $5.5 \mathrm{~cm}$ filter paper to trap evolved $\mathrm{H}_{2} \mathrm{~S}$. Septum lids were placed on the universal tubes which were then transferred to a shaking water bath at $37^{\circ} \mathrm{C}$ and incubated for 6 hours. The reaction was stopped after 6 hours by the injection of 50\% trichloroacetic acid $(0.5 \mathrm{ml})$ via the septum lid into the reaction mixture. To ensure maximum trapping of evolved hydrogen sulphide the reaction was allowed to incubate for a 
further 1 hour in the shaking water bath. The methylene blue assay was used to measure the sulphide concentration of the centre well contents. The contents of the centre wells were transferred to test tubes and the following were added to each tube: $3.5 \mathrm{ml}$ of distilled water, $0.4 \mathrm{ml}$ of $\mathrm{N}, \mathrm{N}$-dimethyl-p-phenyldiamine sulphate $(20 \mathrm{mM}$ in 7.2 $\mathrm{M} \mathrm{HCl}$ ) and $0.4 \mathrm{ml}$ of ferric chloride (30 mM in $1.2 \mathrm{HCl}$ ). The tubes were incubated at room temperature for 20 minutes. The absorbance was measured at $670 \mathrm{~nm}$ on a spectrophotometer (Cecil, Cambridge, UK). Calibration standards were prepared using a $10 \mathrm{mM}$ stock solution of NaHS to produce a standard calibration curve. Sulphide concentrations were measured and the production rate of $\mathrm{H}_{2} \mathrm{~S}$ was calculated. The experiment was run in parallel without L-cysteine in the reaction mixture, as a negative control. The effect of $\mathrm{NO}$ on $\mathrm{H}_{2} \mathrm{~S}$ production was investigated using the NO donor sodium nitroprusside (SNP) (Sigma-Aldrich, Poole, UK). The reaction mixture was incubated with $1 \mu \mathrm{M}$ of SNP. The production of $\mathrm{H}_{2} \mathrm{~S}$ under low oxygen conditions was investigated by flushing nitrogen gas into the universal tubes containing reaction mixture before sealing with septum lids. The concentration of oxygen in the reaction tubes was not measured. All experimental runs involved ten replicates.

\section{Western blotting}

The expression of CBS and CSE was investigated in rat and human intrauterine tissues using Western blotting. Tissue was lysed in lysis buffer and left to incubate on ice for 60 minutes. Supernatants were retained by centrifugation at $14,000 \mathrm{~g}$ for 20 minutes at $4^{\circ} \mathrm{C}$. Supernatant samples (50 $\mu \mathrm{g} / \mu \mathrm{l})$ were prepared for Western blot with loading buffer. Samples were separated on a 10\% SDS-PAGE gel for 55 minutes at $150 \mathrm{~V}$. The transfer of proteins was checked with Ponceau stain (Sigma, Poole, UK). The SDS-PAGE gel was transferred to PVDF membrane (Amersham, Buckinghamshire, UK) at $50 \mathrm{~V}$ for 2 hours. 5\% non-fat dried milk was used to block the membrane. The primary antibodies for CSE and CBS were home made at Lakehead University (Canada). The membrane was then incubated with the primary antibody (dilution 1:500) overnight at $4{ }^{\circ} \mathrm{C}$. Primary antibody was removed by three 5 minute washes with TBST. The membrane was incubated with secondary antibody (dilution 1:5000 for both goat antimouse and goat anti-rabbit (Abcam, Cambridge, UK) for 1 hour at room temperature. Secondary antibody was removed by three 5 minute washes with TBST. The ECL Plus Western Blotting detection kit (Amersham, Little Chalfont, UK) was used to detect the presence of the enzymes using the ChemiDoc EQ imager (Bio-Rad, Hemel Hempstead, UK). The PVDF membranes were reprobed with the loading control $\beta$-actin based on the method used by Liao et al. [19] with some modifications. After incubation with the ECL Plus Western Blotting detection kit, the PVDF membranes were kept in fresh
TBST at $4^{\circ} \mathrm{C}$ for 24 hours. The PVDF membranes were washed three times for 5 minutes with TBST. These membranes were reprobed with $\beta$-actin antibody (Abcam, Cambridge, UK) (dilution 1:1000) in 5\% milk (non-fat dried milk) overnight. The ECL Plus Western Blotting detection kit was used to detect the presence of $\beta$-actin. Rat kidney was used as a positive control for CBS, as it has previously been detected in rat kidney [20]. For CSE the positive control used was rat aorta. Non-pregnant (NP) rat uterus was also investigated for the expression of both CBS and CSE $(n=4)$.

The following rat tissues were investigated: uterus, placenta and fetal membranes (amnion) $(n=4)$. Human tissues investigated were: chorion, amnion, myometrium and placenta $(n=4)$. The Western blotting technique used was qualitative.

\section{Statistical analysis}

$\mathrm{H}_{2} \mathrm{~S}$ production rates in $\mathrm{nM} \mathrm{min}^{-1} \mathrm{~g}^{-1}$ wet tissue are shown as mean $\pm \mathrm{SD}$. Mean production rates were compared using Student's T test for unrelated samples or ANOVA with a LSD posthoc test corrected for repeated tests, as appropriate. $\mathrm{P}<0.05$ was considered statistically significant.

\section{Results \\ Assay validation}

The coefficient of variation for the methylene blue assay was $5.7 \%$. The intrapair correlation was $0.975(\mathrm{P}<0.001)$.

\section{Basal production of $\mathrm{H}_{2} \mathrm{~S}$ in rat liver, rat intrauterine tissues and human placenta}

Rat intrauterine tissue and human placenta homogenates produced $\mathrm{H}_{2} \mathrm{~S}$ from L-cysteine in vitro (Table 1). Rat liver homogenate (positive control) produced $\mathrm{H}_{2} \mathrm{~S}$ at a much higher rate than the rat intrauterine tissues (Table 1 ). The order of $\mathrm{H}_{2} \mathrm{~S}$ production rates was rat liver $>$ human placenta $>$ rat uterus $>$ rat fetal membranes $>$ rat placenta (Table 1).

\section{Endogenous production of $\mathrm{H}_{2} \mathrm{~S}$ in the presence of a nitric oxide donor}

For rat liver there was a trend of increased production of $\mathrm{H}_{2} \mathrm{~S}$ in the presence of the NO donor, however the difference in mean production rates did not reach significance (Table 2). A similar trend was observed for rat uterus and rat placenta homogenates (Table 2). For rat fetal membranes $\mathrm{H}_{2} \mathrm{~S}$ production was significantly elevated in the presence of the NO donor $(\mathrm{p}<0.05)$ (Table 2$)$.

\section{Endogenous production of $\mathrm{H}_{2} \mathrm{~S}$ under low oxygen conditions}

Under low oxygen conditions production of $\mathrm{H}_{2} \mathrm{~S}$ was significantly increased compared to room air oxygen condi- 
Table I: Comparison of mean production rates of $\mathrm{H}_{2} \mathrm{~S}$ from homogenates of rat liver, rat intrauterine tissues and human placenta (nM/ $\mathrm{min} / \mathrm{g}$ ) in the presence and absence (control) of $10 \mathrm{mM} \mathrm{L-cysteine.}$

\begin{tabular}{|c|c|c|c|c|c|}
\hline \multirow[t]{2}{*}{ Tissue } & \multirow[t]{2}{*}{ Treatment } & \multicolumn{3}{|c|}{$\mathrm{H}_{2} \mathrm{~S}$ production rate $(\mathrm{nM} / \mathrm{min} / \mathrm{g})$} & \multirow[t]{2}{*}{ Significance } \\
\hline & & Mean & SD & $\mathrm{n}$ & \\
\hline \multirow[t]{2}{*}{ Rat liver } & Control & 4.0 & 3.5 & 4 & \\
\hline & L-cysteine & 777 & 163 & 4 & $P<0.05$ \\
\hline \multirow[t]{2}{*}{ Rat uterus } & Control & 0 & 0 & 4 & \\
\hline & L-cysteine & 168 & 100 & 4 & $P<0.05$ \\
\hline \multirow[t]{2}{*}{ Rat placenta } & Control & 0 & 0 & 4 & \\
\hline & L-cysteine & II.I & 4.7 & 4 & $P<0.05$ \\
\hline \multirow[t]{2}{*}{ Rat fetal membranes } & Control & 0 & 0 & 4 & \\
\hline & L-cysteine & 22.3 & 15.0 & 4 & $P<0.05$ \\
\hline \multirow[t]{2}{*}{ Human placenta } & Control & 0 & 0 & 4 & \\
\hline & L-cysteine & 200 & 102 & 4 & $P<0.05$ \\
\hline
\end{tabular}

A value of 0 indicates below the level of detection.

tions for rat liver, uterus and fetal membranes $(\mathrm{P}<0.05)$, but not rat placenta (Table 3). For human placenta there was a significant increase in $\mathrm{H}_{2} \mathrm{~S}$ production under low oxygen conditions $(\mathrm{P}<0.05)$ (Table 3$)$.

\section{Expression of CBS and CSE in rat intrauterine tissues}

Figure 1 shows the expression of CBS in rat intrauterine tissues. Expression of CBS was detected at $15 \mathrm{kDa}$ in rat tissues (Fig. 1a), while expression of CSE was detected at $43 \mathrm{kDa}$ in all tissues investigated (Fig. 1b). $\beta$-actin was used as a loading control for each Western blot and was detected at $42 \mathrm{kDa}$.
Expression of CBS and CSE in human intrauterine tissues Expression of CBS was detected at about $48 \mathrm{kDa}$ in all human tissue samples (Fig. 1c). The same human samples were used to investigate the expression of CSE in intrauterine tissues. CSE expression was detected at $43 \mathrm{kDa}$ in all human tissues (Fig. 1d). $\beta$-actin was used as loading controls for these Western blots and expression was detected at $42 \mathrm{kDa}$.

\section{Discussion}

Endogenous production of $\mathrm{H}_{2} \mathrm{~S}$ in intrauterine tissues

The physiological role of $\mathrm{H}_{2} \mathrm{~S}$ in the reproductive system has not been fully investigated. Sidhu et al. [18] previously showed that L-cysteine and NaHS relaxed pregnant rat

Table 2: Effect of a nitric oxide donor on mean production rates of $\mathrm{H}_{2} \mathrm{~S}$ from homogenates of rat liver and intrauterine tissues ( $\mathrm{nM} /$ $\mathrm{min} / \mathrm{g}$ ) in the presence and absence (negative control) of $10 \mathrm{mM} \mathrm{L-cysteine.}$

\begin{tabular}{|c|c|c|c|c|c|}
\hline \multirow[t]{2}{*}{ Tissue } & \multirow[t]{2}{*}{ Treatment } & \multicolumn{3}{|c|}{$\mathrm{H}_{2} \mathrm{~S}$ production rate $(\mathrm{nM} / \mathrm{min} / \mathrm{g})$} & \multirow[t]{2}{*}{ Significance } \\
\hline & & Mean & SD & $\mathrm{n}$ & \\
\hline \multirow[t]{3}{*}{ Rat liver } & -ve control & 4.0 & 3.5 & 4 & \\
\hline & L-cysteine & 575 & 172 & 4 & \\
\hline & + NO donor & 596 & 174 & 4 & NS \\
\hline \multirow[t]{3}{*}{ Rat uterus } & -ve control & 0 & 0 & 4 & \\
\hline & L-cysteine & 438 & 277 & 4 & \\
\hline & + NO donor & 433 & 224 & 4 & NS \\
\hline \multirow[t]{3}{*}{ Rat placenta } & -ve control & 0 & 0 & 4 & \\
\hline & L-cysteine & 45.7 & 51.6 & 4 & \\
\hline & + NO donor & 51.6 & 26.2 & 4 & NS \\
\hline \multirow[t]{3}{*}{ Rat fetal membranes } & -ve control & 0 & 0 & 4 & \\
\hline & L-cysteine & 43.4 & 20.3 & 4 & \\
\hline & $+\mathrm{NO}$ donor & 57.4 & 31.5 & 4 & $P<0.05$ \\
\hline
\end{tabular}

A value of 0 indicates below the level of detection. 
Table 3: Effect of a low oxygen environment on mean production rates of $\mathrm{H}_{2} \mathrm{~S}$ from homogenates of rat liver, rat intrauterine tissues and human placenta $(\mathrm{nM} / \mathrm{min} / \mathrm{g})$ in the presence and absence (negative control) of $10 \mathrm{mM}$ L-cysteine.

\begin{tabular}{|c|c|c|c|c|c|}
\hline \multirow[t]{2}{*}{ Tissue } & \multirow[t]{2}{*}{ Treatment } & \multicolumn{3}{|c|}{$\mathrm{H}_{2} \mathrm{~S}$ production rate $(\mathrm{nM} / \mathrm{min} / \mathrm{g})$} & \multirow[t]{2}{*}{ Significance } \\
\hline & & Mean & SD & $\mathrm{n}$ & \\
\hline \multirow[t]{3}{*}{ Rat liver } & -ve control & 4.0 & 3.5 & 4 & \\
\hline & L-cysteine & 331 & 269 & 4 & \\
\hline & Low $\mathrm{O}_{2}$ & 454 & 205 & 4 & $P<0.05$ \\
\hline \multirow[t]{3}{*}{ Rat uterus } & -ve control & 0 & 0 & 4 & \\
\hline & L-cysteine & 405 & 432 & 4 & \\
\hline & Low $\mathrm{O}_{2}$ & 606 & 620 & 4 & $P<0.05$ \\
\hline \multirow[t]{3}{*}{ Rat placenta } & -ve control & 0 & 0 & 4 & \\
\hline & L-cysteine & 20 & 10.9 & 4 & \\
\hline & Low $\mathrm{O}_{2}$ & 17.1 & 11.2 & 4 & NS \\
\hline \multirow[t]{3}{*}{ Rat fetal membranes } & -ve control & 0 & 0 & 4 & \\
\hline & L-cysteine & 146 & 120 & 4 & \\
\hline & Low $\mathrm{O}_{2}$ & 490 & 218 & 4 & $P<0.05$ \\
\hline \multirow[t]{3}{*}{ Human placenta } & -ve control & 0 & 0 & 4 & \\
\hline & L-cysteine & 200 & 102 & 4 & \\
\hline & Low $\mathrm{O}_{2}$ & 397 & 326 & 4 & $P<0.05$ \\
\hline
\end{tabular}

A value of 0 indicates below the level of detection.

uterus in vitro, however the endogenous production of $\mathrm{H}_{2} \mathrm{~S}$ in intrauterine tissue was not investigated in that study. In the present study we are the first to report the production of $\mathrm{H}_{2} \mathrm{~S}$ in rat and human intrauterine tissues. The baseline production of $\mathrm{H}_{2} \mathrm{~S}$ in rat intrauterine tissues was established in the present study. The results showed that in the absence of additional L-cysteine all rat intrauterine tissues produced very low levels of $\mathrm{H}_{2} \mathrm{~S}$, the greatest value was for rat liver $\left(4.01 \pm 3.5 \mathrm{~min}^{-1} \mathrm{~g}\right.$ wet tissue $\left.{ }^{-1}\right)$. The tissue homogenates would have contained some blood and a small concentration of endogenous L-cysteine would have been present. It is also possible that when the homogenates were acidified with trichloroacetic acid some sulphide ions present were driven off as $\mathrm{H}_{2} \mathrm{~S}$.

With the addition of $10 \mathrm{mM}$ L-cysteine a significant increase in the production of $\mathrm{H}_{2} \mathrm{~S}$ was observed in all tissues. Rat liver produced $\mathrm{H}_{2} \mathrm{~S}$ at a significantly higher production rate in comparison to all intrauterine tissues; this is possibly due to the high expression of CSE in rat liver $[6,7]$. The present study showed that rat uterus produced $\mathrm{H}_{2} \mathrm{~S}$ at a greater rate than rat placenta and fetal membranes; the lowest production rate was observed in rat placenta. Human placenta exhibited significant $\mathrm{H}_{2} \mathrm{~S}$ production. The present study showed that $\mathrm{H}_{2} \mathrm{~S}$ can be produced from L-cysteine in intrauterine tissues.

\section{The endogenous production of $\mathrm{H}_{2} \mathrm{~S}$ in the presence of a} nitric oxide donor

Earlier studies have demonstrated the effect of NO on the production of $\mathrm{H}_{2} \mathrm{~S}$. Zhao et al. [12] demonstrated that NO up-regulated the production of $\mathrm{H}_{2} \mathrm{~S}$. In the present study comparison of treatments of L-cysteine and the $\mathrm{NO}$ donor showed no significant difference in the production of $\mathrm{H}_{2} \mathrm{~S}$, showing that the NO donor did not affect the production of $\mathrm{H}_{2} \mathrm{~S}$. Similar results were observed with rat uterus and placenta. In rat fetal membranes the presence of the NO donor showed a significantly $(\mathrm{P}<0.05)$ elevated production rate in comparison to the L-cysteine treatment alone (Table 2). A similar result was observed by Zhao et al. [12] where the production of $\mathrm{H}_{2} \mathrm{~S}$ was up-regulated by SNP in rat aortic tissue. Zhao et al. [12] demonstrated that NO upregulated the production of $\mathrm{H}_{2} \mathrm{~S}$ via the cGMP pathway. The mechanism by which $\mathrm{NO}$ affects the $\mathrm{H}_{2} \mathrm{~S}$ production rate was not investigated in this study. It is not clear why the augmenting effect of SNP only reached significance in rat fetal membranes.

\section{The endogenous production of $\mathrm{H}_{2} \mathrm{~S}$ under low oxygen conditions}

The present study is the first to demonstrate the increase in measured production of $\mathrm{H}_{2} \mathrm{~S}$ under low oxygen conditions in rat and human intrauterine tissues. The production rate of $\mathrm{H}_{2} \mathrm{~S}$ was significantly increased $(\mathrm{P}<0.05)$ in rat liver under low oxygen conditions. Similar results were observed for rat uterus (Table 3). For rat placenta there was no significant difference in the production rates of 
A

CBS

Fetal
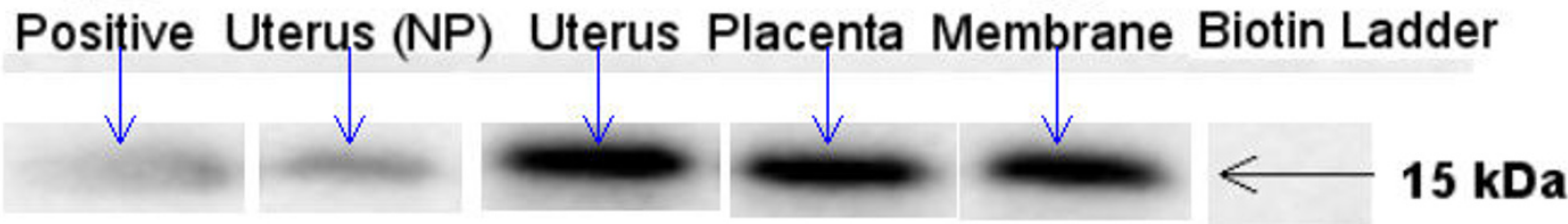

B

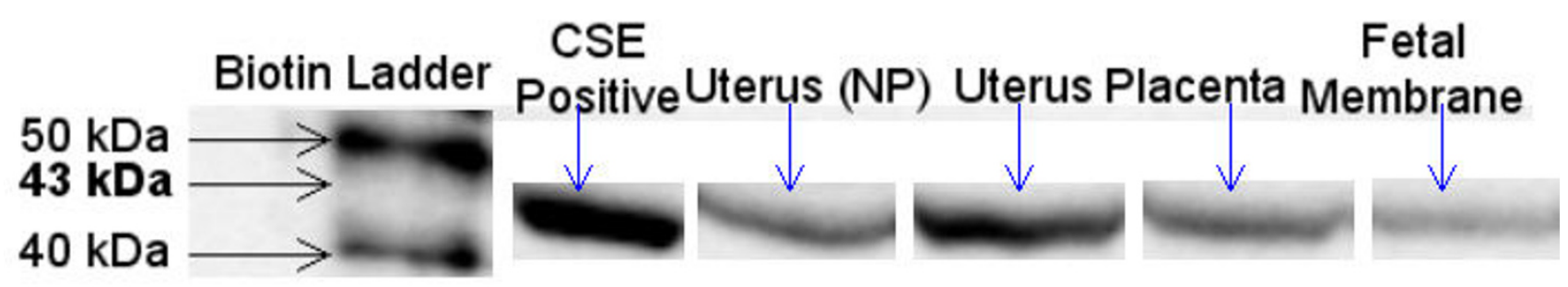

C

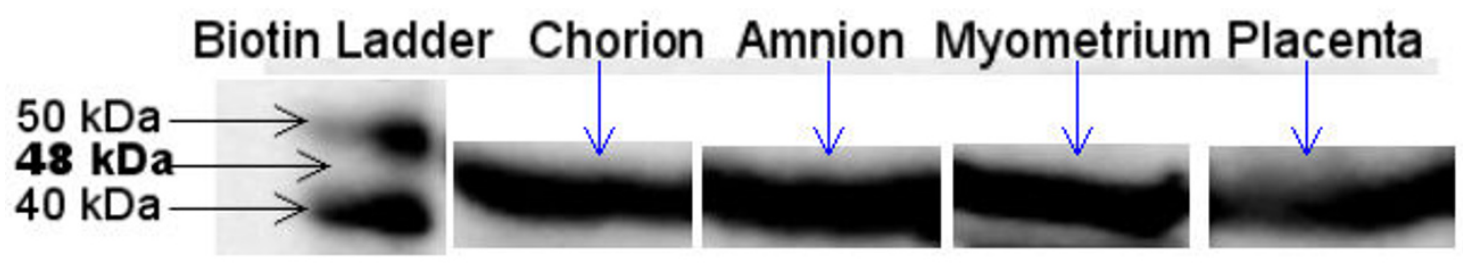

D

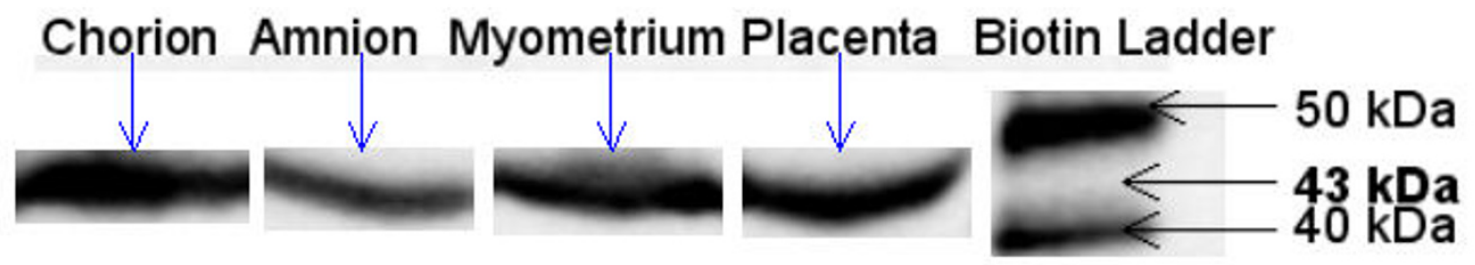

Figure I

Expression of CBS and CSE enzymes in rat and human intrauterine tissues. A Expression of CBS at $15 \mathrm{kDa}$ in rat intrauterine tissues. Expression of CBS was detected in pregnant and non-pregnant rat uterus, placenta and fetal membranes. $B$ Expression of CSE at $43 \mathrm{kDa}$ in rat intrauterine tissues. Expression of CSE was detected in pregnant and non-pregnant rat uterus, placenta and fetal membranes. C Expression of CBS at $48 \mathrm{kDa}$ in human intrauterine tissues. Expression of CBS was detected in human chorion, amnion, myometrium and placenta, D Expression of CSE at $43 \mathrm{kDa}$ in human intrauterine tissues. Expression of CSE was detected in human chorion, amnion, myometrium and placenta. 
$\mathrm{H}_{2} \mathrm{~S}$ under normal and low oxygen conditions. Rat fetal membranes followed the same trend as rat liver and rat uterus under normal and low oxygen conditions. Under low oxygen conditions the production rate of $\mathrm{H}_{2} \mathrm{~S}$ was significantly elevated $(\mathrm{P}<0.05)$. The present study also investigated the endogenous production of $\mathrm{H}_{2} \mathrm{~S}$ in human placenta under normal and low oxygen conditions. It is not clear why a significant increase was seen for human placenta, but not rat placenta. A significant $(\mathrm{P}<0.05)$ increase in $\mathrm{H}_{2} \mathrm{~S}$ production was observed in human placenta under low oxygen conditions. Low oxygen conditions were used as hypoxia is associated with preeclampsia, where poor placental function can reduce the supply of oxygen and nutrients to the fetus resulting in intrauterine growth restriction (IUGR) and other placental dysfunctions. Hypoxia can also bring about other preeclamptic features such as the release of proinflammatory cytokines and oxidative stress [21-23]. Hypoxic conditions can also reduce the uteroplacental perfusion, which may lead to inflammatory conditions i.e. oxidative stress [23]. In the present study we found that the endogenous production of $\mathrm{H}_{2} \mathrm{~S}$ under low oxygen conditions was elevated in rat uterus, fetal membranes and in human placenta in vitro. It is possible that under atmospheric oxygen conditions some oxidation of evolved $\mathrm{H}_{2} \mathrm{~S}$ could occur, thus reducing the amount of trapped $\mathrm{H}_{2} \mathrm{~S}$ in the assay. Under low oxygen conditions perhaps less $\mathrm{H}_{2} \mathrm{~S}$ was oxidised, leading to increased measured production rates of $\mathrm{H}_{2} \mathrm{~S}$. However, if it were a simple chemical effect then it would be expected to affect all $\mathrm{H}_{2} \mathrm{~S}$ production measurements equally, but this was not the case (Table 3). For example, measured $\mathrm{H}_{2} \mathrm{~S}$ production from rat placenta was not increased under low oxygen conditions. It seems more likely that the CBS and CSE enzymes could be directly affected by oxygen. CBS contains heme in its structure, which could bind oxygen and affect enzyme function. In comparison, CSE does not contain heme so an alternative or novel mechanism could be involved. Clearly there is a difference between low oxygen incubation for tissue homogenates in vitro and physiological hypoxia in vivo. The enzyme function of CBS and CSE appear to be affected by oxygen levels. It is possible that increased production of $\mathrm{H}_{2} \mathrm{~S}$ under hypoxic conditions could have a role in the pathology of pre-eclampsia.

\section{Expression of cystathionine $\beta$-synthase (CBS) and cystathionine $\gamma$-lyase (CSE)}

The human CBS gene has been mapped to chromosome 2 and contains 23 exons. Exons $1-14$ and 16 encode the CBS enzyme. The molecular weight of CBS is 160,000 , and in human and rat liver the primary translational product of the CBS gene gives rise to tetrameric subunits of 63 $\mathrm{kDa}$. These subunits are composed of 551 amino acids residues, and the enzyme also contains the pyridoxal 5'phophaste and haem molecule per subunit essential for its activity $[24,25]$. The haem molecule could be the direct target of NO as it can bind to haem with high affinity. The proteolytic cleavage of the $63 \mathrm{kDa}$ subunit yields a $48 \mathrm{kDa}$ dimer subunit (40-413 amino acid residue), which is accompanied by a 60 -fold increase in the enzyme's specific activity with physiological concentrations of homocysteine [24-27].

The presence of CSE has previously been found in rat liver and in a variety of species including: Neurospora crassa, Aspergillus nidulans, Saccharomyces cerevisiae and Saccharomycopsis lipoltic [28-30]. CSE has a molecular weight of $166 \mathrm{kDa}$. Like rat CBS, rat CSE is also composed of 4 identical tetrameric subunits at $43 \mathrm{kDa}$ and require pyridoxal 5 '-phophaste for their activity [28,31]. The cDNA sequence of rat CSE in comparison to related E. coli enzymes (cystathionine $\gamma$-synthase and cystathionine $\beta$ lyase) share a common ancestral gene as well as identical tetrameric subunits at $43 \mathrm{kDa}$. These enzymes from E. coli are also pyridoxal 5'-phophaste dependent [6]. Expression of CSE is mainly abundant in vascular tissues, while expression is increased in fetal liver in later stages of development $[9,28]$.

The expression of CSE and CBS has previously been reported in mammalian tissues. CBS is the main $\mathrm{H}_{2} \mathrm{~S}$ producing enzyme in brain tissue [8], while CSE is responsible for $\mathrm{H}_{2} \mathrm{~S}$ production in vascular tissues [9].

The presence of CBS and CSE has not been previously reported in rat or human intrauterine tissues. In the present study, the expression of CBS and CSE was detected in rat and human intrauterine tissues qualitatively by Western blotting. CBS was detected at $15 \mathrm{kDa}$ in rat kidney (positive control), non-pregnant uterus, pregnant uterus, placenta and fetal membranes (Fig. 1a). It is not clear why a fragment of CBS was detected at $15 \mathrm{kDa}$ in rat tissue, but at $48 \mathrm{kDa}$ in human tissue. Skovby et al.(1984) [24] previously reported a $15 \mathrm{kDa}$ peptide cleaved from CBS by proteolysis. As the primary antibody used was polyclonal it is possible that it bound to an epitope on the 15 $\mathrm{kDa}$ fragment from rat CBS. CSE was detected at approximately $43 \mathrm{kDa}$ in rat aorta (positive control), non-pregnant uterus, pregnant uterus, placenta and fetal membranes (Fig. 1b). These results are in accordance with Cheng et al. [9] who previously reported the expression of CSE in rat vascular tissues at $43 \mathrm{kDa}$.

The present study also detected the presence of CBS and CSE in human intrauterine tissues. Expression of CBS was detected in human chorion, amnion, myometrium and placenta (Fig. 1c). A band at $48 \mathrm{kDa}$ was detected in all tissues, suggesting CBS expression. However, these results do not agree with the previous findings by Ratnam $e t$ al. [32] who reported expression of CBS at $63 \mathrm{kDa}$ in rat liver 
cells. It has been previously reported that rat liver CBS has a subunit at $48 \mathrm{kDa}$ which can be produced by proteolytic cleavage of the $63 \mathrm{kDa}$ subunit $[7,24]$. The present study detected a band at about $48 \mathrm{kDa}$, which is likely to be the subunit expression at $48 \mathrm{kDa}$ of CBS. The present study also investigated the expression of CSE in human chorion, amnion, myometrium and placenta. The results detected expression of CSE at $43 \mathrm{kDa}$ in all human tissues (Fig. 1d). These results agree with similar findings of CSE expression detected at $43 \mathrm{kDa}$ in rat vascular tissues [9].

This is the first study to report the detection of both CBS and CSE in rat and human intrauterine tissues and the production of $\mathrm{H}_{2} \mathrm{~S}$ by these tissues. The results demonstrated the endogenous production of $\mathrm{H}_{2} \mathrm{~S}$ in rat and human intrauterine tissues via CBS and CSE enzymes.

\section{Conclusion}

Basal production of $\mathrm{H}_{2} \mathrm{~S}$ was demonstrated in rat uterus, placenta, fetal membranes and human placenta. The endogenous production of $\mathrm{H}_{2} \mathrm{~S}$ was up-regulated by the NO donor SNP in rat fetal membranes. Exposure of cell homogenates from rat liver, uterus, fetal membranes and human placenta, to low oxygen levels increased $\mathrm{H}_{2} \mathrm{~S}$ production rates. The presence of CBS and CSE enzymes was demonstrated, for the first time, in rat and human intrauterine tissues. Endogenously produced $\mathrm{H}_{2} \mathrm{~S}$ could possibly have a role in the pathology of pre-eclampsia, however further investigation of the role of $\mathrm{H}_{2} \mathrm{~S}$ in the reproductive system is required.

\section{Competing interests}

The authors declare that they have no competing interests.

\section{Authors' contributions}

PP conducted the laboratory work, analysed the data and drafted the paper. MV provided human tissue and ethical approval. JH provided biochemical advice and reviewed the draft paper. RW provided the primary antibodies, gave advice and reviewed the draft paper. RJC designed the study and amended the paper. All authors read and approved the final manuscript.

\section{Acknowledgements}

The authors are grateful to Mark Bodycote for expert care of the animals.

\section{References}

I. Buhimschi I, Yallampalli C, Dong YL, Garfield RE: Involvement of a nitric oxide-cyclic guanosine monophosphate pathway in control of human uterine contractility during pregnancy. Am J Obstet \& Gynecol 1995, I72: 1577-I 584.

2. Yallampalli C, Dong $Y$, Gangula PR, Fang $L$ : Role and regulation of nitric oxide in uterus during pregnancy and parturition. I Soc Gynecol Invest 1998, 5(2):58-67.

3. Acevedo $\mathrm{CH}$, Ahmed A: Hemeoxygenase-I inhibits human myometrial contractility via carbon monoxide and is upregulated by progesterone during pregnancy. J Clin Invest 1998, I 0 I(5):949-955.
4. Wang R: Two's company, three's a crowd - can $\mathrm{H}_{2} \mathbf{S}$ be the third endogenous gaseous transmitter? J Fed Am Soc Expl Biol 2002, 16:1792-1798.

5. Stipanuk MH, Beck PW: Charcaterization of the enzymic capacity for cysteine desulphhydration in liver and kidney of the rat. J Biochem 1982, 206:267-277.

6. Erickson PF, Maxwell IH, Su LJ, Baumann M, Glode LM: Sequence of cDNA for rat cystathionine gamma-lyase and comparison of deduced amino acid sequence with related Escherichia coli enzymes. Biochem J 1990, 269(2):335-340.

7. Swaroop M, Bradley K, Ohura T, Tahara T, Roper MD, Rosenberg LE, Kraus JP: Rat cystathionine beta-synthase. Gene organization and alternative splicing. J Biol Chem I992, 267( 16): I |455- I I 46 I.

8. Abe K, Kimura $\mathrm{H}$ : The possible role of hydrogen sulphide as an endogenous neuromodulator. J. Neurosci 1996, 16(3): 1066-107|.

9. Cheng Y, Ndisang JF, Tang G, Cao K, Wang R: Hydrogen sulphideinduced relaxation of resistance mesenteric artery beds of rats. Am J Physiol 2004, 287(5):H23 16- $\mathrm{H} 2323$.

10. Smythe CV: The utilization of cysteine and cystine by rat liver with the production of hydrogen sulphide. J Biol Chem 1942, 142:387-400.

II. Hosoki R, Matsuki N, Kimura H: The possible role of hydrogen sulphide as an endogenous smooth muscle relaxant in synergy with nitric oxide. Biochem Biophys Res Comm 1997, 237(3):527-53I.

12. Zhao W, Ndisang JF, Wang R: Modulation of endogenous production of $\mathrm{H}_{2} \mathbf{S}$ in rat tissues. Can J Physiol Pharmacol 2003, $8 \mathrm{I}: 848-853$.

13. Zhao W, Zhang J, Lu Y, Wang R: The vasorelaxant effect of HS as a novel endogenous gaseous $K_{A T P}$ channel opener. EMBOJ 200I, 20:6008-6016.

14. Bhatia M, Wong FL, Fu D, Lau HY, Moochhala SM, Moore PK: Role of hydrogen sulphide in acute pancreatitis and associated lung injury. J Fed Am Soc Exp Biol 2005, 19(6):623-625.

15. Mok YY, Atan MS, Yoke Ping C, Zhong Jing W, Bhatia M, Moochhala $S$, Moore PK: Role of hydrogen sulphide in haemorrhagic shock in the rat: protective effect of inhibitors of hydrogen sulphide biosynthesis. Br J Pharmacol 2004, I 43(7):88I-889.

16. Collin M, Anuar FB, Murch O, Bhatia M, Moore PK, Thiemermann C: Inhibition of endogenous hydrogen sulphide formation reduces the organ injury caused by endotoxemia. Br J Pharmacol 2005, 1 46:498-505.

17. Teague B, Asiedu S, Moore PK: The smooth muscle relaxant effect of hydrogen sulphide in vitro:evidence for a physiological role to control intestinal contractility. Br J Pharmacol 2002, 137:139-145.

18. Sidhu R, Singh M, Samir G, Carson RJ: L-cysteine and sodium hydrosulphide inhibit spontaneous contractility in isolated pregnant uterine strips in vitro. Pharmacol Toxicol 200I, 88(4): $198-203$.

19. Liao L, Xu X, Wargovich MJ: Direct reprobing with anti-b-actin as an internal control for western blot analysis. Biotechniques 2000, 28:216-218.

20. Roper MD, Kraus JP: Rat cystathionine beta-synthase: expression of four alternatively spliced isoforms in transfected cultured cells. Arch Biochem Biophys 1992, 298(2):5 I4-52I.

21. Agarwal A, Gupta S, Sharma R: Role of oxidative stress in female reproduction. Reprod Biol Endocrinol 2005, I 4(3):28.

22. Chappell LC, Seed PT, Kelly FJ, Briley A, Mallet Al, Hunt BJ, Charnock-Jones DS, Poston L: Vitamin $E$ and $C$ supplementation in women at risk of pre-eclampsia is associated with changes in indices of oxidative stress and placental function. Am J Obstet Gynecol 2002, 187:777-784.

23. Soleymanlou N, Jurisica I, Nevo O, letta F, Zhang X, Zamudio S, Post $M$, Caniggia I: Molecular Evidence of Placental Hypoxia in Preeeclampsia. J Clin Endocrinol Metabol 2005, 90(7):4299-4308.

24. Skovby F, Kraus JP, Rosenberg LE: Biosynthesis and proteolytic activation of cystathionine beta-synthase in rat liver. J Biol Chem 1984, 259(I):588-593.

25. Kraus JP, Packman S, Fowler B, Rosenberg LE: Purification and properties of cystathionine $\beta$-synthase from human liver. J Biol Chem 1978, 253:6523-6528.

26. Kraus JP, Rosenberg LE: Cystathionine $\beta$-synthase from human liver: Improved purification scheme and additional charac- 
terization of the enzyme in crude and pure form. Arch Biochem Biophys 1983, 222:44-52.

27. Kraus JP: Cystathionine beta-synthase (human). Methods Enzymol 1987, I 43:388-394.

28. Nagasawa T, Kanzaki H, Yamada H: Cystathionine gamma-lyase of Streptomyces phaeochromogenes. The occurrence of cystathionine gamma-lyase in filamentous bacteria and its purification and characterization. I Biol Chem 1984, 259(16): 10393-10403.

29. Matsuo Y, Greenberg DM: A crystalline enzyme that cleaves homoserine and cystathionine I. Isolation procedure and some physiochemical properties. I Biol Chem 1958, 230:545-560.

30. Delavier-Klutchko C, Flavin M: Enzymatic synthesis and cleavage of cystathionine in fungi and bacteria. J Biol Chem 1965, 240:2537-2549.

31. Clausen T, Huber R, Prade L, Wahl MC, Messerschmidt A: Crystal structure of Escherichia coli cystathionine gamma-synthase at I.5 A resolution. EMBO J 1998, 17(23):6827-6838.

32. Ratnam S, Maclean KN, Jacobs RL, Brosnan ME, Kraus JP, Brosnan JT: Hormonal regulation of cystathionine beta-synthase expression in liver. J Biol Chem 2002, 277(45):42912-429|8.

Publish with Bio Med Central and every scientist can read your work free of charge

"BioMed Central will be the most significant development for disseminating the results of biomedical research in our lifetime."

Sir Paul Nurse, Cancer Research UK

Your research papers will be:

- available free of charge to the entire biomedical community

- peer reviewed and published immediately upon acceptance

- cited in PubMed and archived on PubMed Central

- yours - you keep the copyright

Submit your manuscript here:

http://www.biomedcentral.com/info/publishing_adv.asp 